\title{
Peripheral neuroectodermal tumour : a clinicopathological and immunohistochemical study of seven cases in Sri Lanka
}

\author{
N. Ratnatunga' \\ The Ceylon Journal of Medical Science 1996; 39: 51-56 \\ Summary
}

The clinicopathological and immunohistochemical features of 7 cases of peripheral neuroectodermal tumour were documented. Children and adults were affected. The tumours were found in both bone and soft tissue. All tumours were positive for neurone specific enolase. Some were positive for PGP 9.5 neurofilaments and $0-13$, in addition. Cytoplasmic glycogen was variable. Some tumours showed good neural differentiation. In general the tumours had an aggressive behaviour.

\section{Introduction}

Peripheral neuroectodermal tumour (PNET) is a malignant neoplasm composed of small round cells, and can resemble many other small cell tumours such as Ewing's sarcoma, neuroblastoma and lymphoma $(1,2)$. It is reported to affect children and young adults mainly(1). It is one of the entities that comprise the "small round cell tumours" - in histopathological practice.

PNET's have been described in many locations, including abdomen, retroperitoneum and the extremities(3). These tumours have not been hitherto reported in the literature in Sri Lanka, which is most likely to be due to underdiagnosis of the condition, as its definitive diagnosis requires special staining procedures to be performed on tissues.

The aim of this study was to document the clinicopathological features of malignant peripheral neuroectodermal tumours, the first report in Sri Lanka.
Materials and methods

Tissue from seven cases referred to the Department of Pathology. University of Peradeniya, were utilised for this study. The tissues were fixed in $10 \%$ formalin and paraffin embedded. Four micron sections were cut from all available blocks, and stained with haematoxylin and eosin, periodic acid schiff and the Gordon and Sweet's reticulin stains. Further sections were immunostained for Neurone Specific Enolase (NSE), Leucocyte Common Antigen (LCA), muscle actin, human desmin, cytokeratin (CK), Epithelial membrane antigen (EMA), and Carcino Embryonic Antigen (CEA), with primary antibodies, DAKO - NSE $1 / 50$, DAKO-LCA 1/50, DAKO-Muscle ACTIN HHF 35 1/50, DAKO-Desmin-MO76 1/50, DAKOCKI 1/50, DAKO-EMA E $291 / 50$ and CEAA115 $1 / 100$ respectively, followed by a three stage strept avidin biotin-peroxidase staining system. The immuno stains for NSE were double checked at a reference centre abroad in all except case 3.

In addition to this, immunostaining for neurofilaments, O-13, and PGP 9.5, were carried out on the same tissue at the same reference centre. All sections were examined by the author. The clinical details were obtained from the referring clinicians.

Results

\section{Clinical features}

The study group consisted of 7 patients, five of whom were males. The clinical features are shown in Table 1. The ages ranged from 9-51 years. The location of the tumours varied, and 
all tumours except that in case one presented as painless rapidly growing masses. The duration of the lesions were under 10 months, except case one being of 1 years duration. Case 1 had a painful tumour which had disseminated to the chest wall, lungs and pleura, and the patient also had fever.
Case 7 died 3 years after diagnosis, of metastases to lymph nodes and lungs, despite several excisions of the primary tumour and chemotherapy.

The outcome in three are not known.

Table 1. Clinical features of 7 patients with PNET

\begin{tabular}{|c|c|c|c|c|c|c|}
\hline $\begin{array}{l}\text { Case } \\
\text { No. }\end{array}$ & Age & Sex & Location & $\begin{array}{l}\text { Duration at } \\
\text { diagnosis }\end{array}$ & Radiology & $\begin{array}{l}\text { Treatment- } \\
\text { Outcome }\end{array}$ \\
\hline 1. & 28 & F & $\begin{array}{l}\text { Painful anterior } \\
\text { chest wall } \\
\text { lump. }\end{array}$ & 01 year & $\begin{array}{l}\text { Tumour of the } 4 \text { th } \\
\text { rib extending into } \\
\text { lungs and pleura }\end{array}$ & $\begin{array}{l}\text { Died within a few } \\
\text { weeks of diagnosis. }\end{array}$ \\
\hline 2. & 07 & $\mathbf{M}$ & Eye lid lump & 02 weeks & & NK \\
\hline 3. & 42 & $\mathrm{~F}$ & Neck mass & 01 month & & NK \\
\hline 4. & 09 & $\mathrm{M}$ & $\begin{array}{l}\text { Shoulder } \\
\text { mass }\end{array}$ & 02 months & $\begin{array}{l}\text { Erosion head of } \\
\text { femur }\end{array}$ & $\begin{array}{l}\text { Died with lung } \\
\text { metastasis } 2 / 52 \text { after } \\
\text { chemotherapy }\end{array}$ \\
\hline 5. & 25 & M & $\begin{array}{l}\text { Upper arm } \\
\text { swelling }\end{array}$ & 10 months & $\begin{array}{l}\text { Destructive lesion } \\
\text { upper humerus. }\end{array}$ & NK. \\
\hline 6. & 26 & $\mathbf{M}$ & $\begin{array}{l}\text { Multiple tumour } \\
\text { deposits in } \\
\text { scalp, orbits \& } \\
\text { bone marrow }\end{array}$ & 03 months & & $\begin{array}{l}\text { Responded well to } \\
\text { chemotherapy. } \\
\text { Further outcome NK. }\end{array}$ \\
\hline 7. & 51 & $\mathbf{M}$ & $\begin{array}{l}\text { Tumour of calf } \\
\text { muscle. } \\
\text { Metastases in lymph } \\
\text { nodes and lungs }\end{array}$ & 03 months & & $\begin{array}{l}\text { Died } 3 \text { years after } \\
\text { diagnosis. Treated } \\
\text { with several excisions } \\
\text { and chemotherapy. }\end{array}$ \\
\hline \multicolumn{2}{|c|}{ F: Female } & & M: Male & \multicolumn{2}{|c|}{ NK: Not known. } & \\
\hline
\end{tabular}

Case 6 had multiple scalp lumps, and left sided exophthalmos, destruction of the right eye and bone marrow infiltration by the tumour. These were probably secondaries, from an undisclosed primary. The tumour regressed with chemotheraphy - but the final outcome is not known.

Cases 1 and 4 died within a few weeks of diagnosis.
Pathological and immunohistochemical features

Macroscopically the tumour tissue had a fleshy consistency and a whitish cut surface. A variety of histological appearances were seen. Some showed a lobular architecture, perivascular pseudorosettes, and true rosettes (Fig. 1A). Others showed nondescript diffuse sheets of small cells, with scanty cytoplasm (Fig. 1B). The 


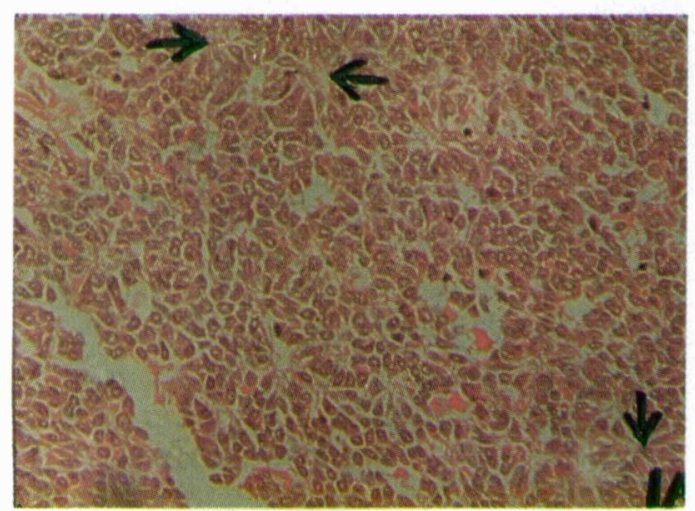

Fig. 1A Small cell tumour with rosettes (arrows). Haematoxylin and Eosin (x 120).

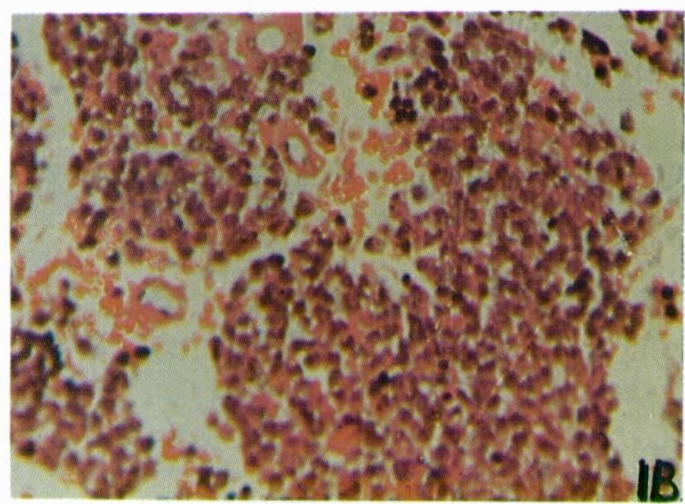

Fig. 1B Sheets of small cells with no particular arrangement. Haematoxylin and Eosin (x 120).

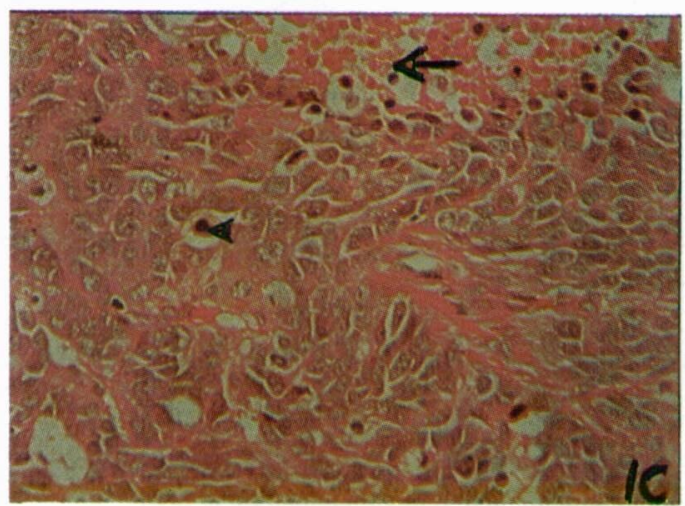

Fig. 1C Tumour composed of larger cells. Foci of necrosis - Arrow. Apoptic figures Arrowhead. Haematoxylin and Eosin (x 120).

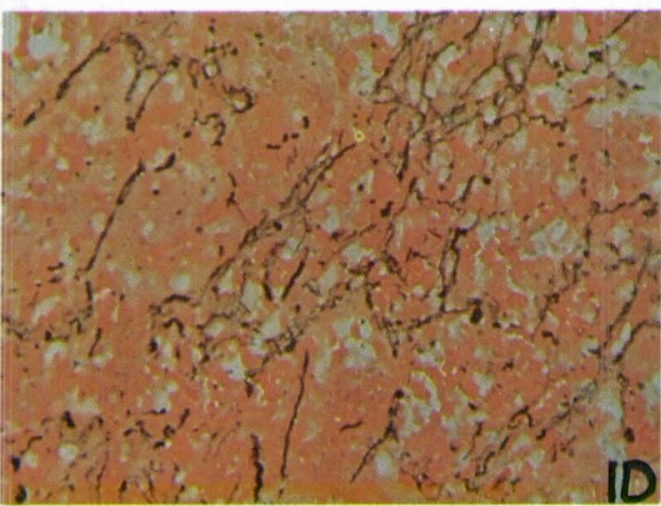

Fig. 1D Reticulin fibres staining black sparse fibres around large clusters of cells. Gordan and Sweet's reticulin stain (x 120).

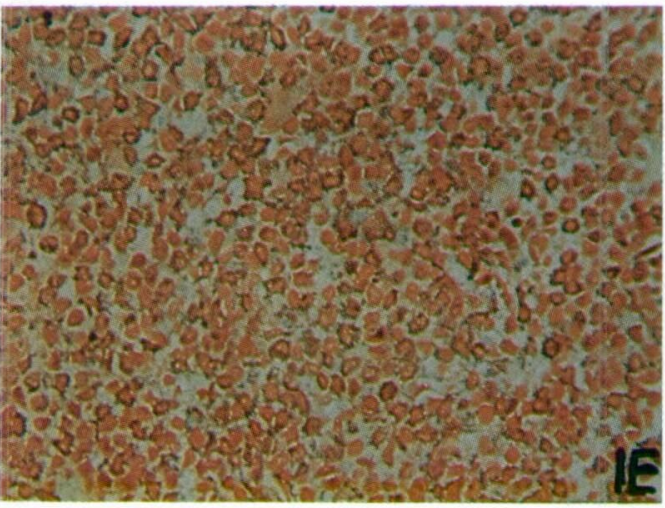

Fig. 1E Pericellular deposits of silver. Gordon and Sweet's reticulin (x 120).

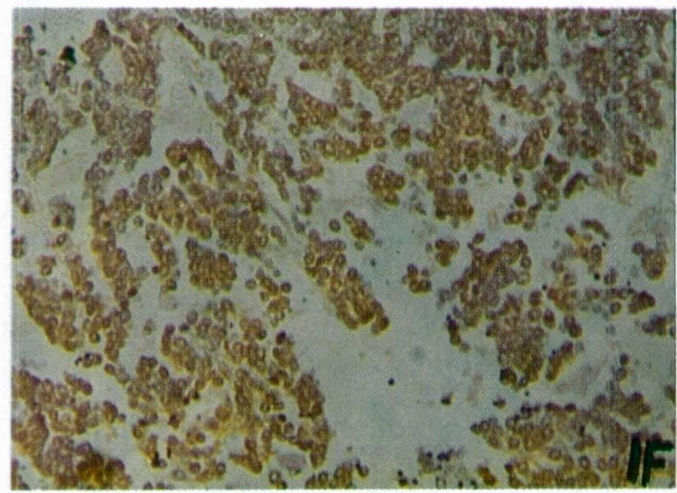

Fig. 1F Cytoplasmic positivity for NSE staining brown. Streptavidin biotin immunoperoxidase (x 120). 
cells were generally small, except in case 3 which showed larger cells (Fig. 1C). The cellular nuclei were small, hyperchromatic, and showed small nucleoli occasionally. Case 3 showed larger cells, and well formed rosettes. This case also showed many mitotic figures, apoptotic cells, and areas of necrosis (Fig. 1C).

The reticulin pattern was varied - ranging from sparse to pricellular deposition of silver (Fig. 1D and 1E). Variable amounts of fibrosis were also seen.

On immunostaining all tumours showed strong cytoplasmic positivity for NSE (Fig. $1 \mathrm{~F}$ and Table 2.)

Cases 1, 4, 6 and 7 were positive for PGP 9.5. O - 13 was positive in case 2. Positivity for neurofilaments were seen in cases 5 \& 7 . All epithelial markers, muscle markers and leucocyte common antigen were negative (Table 2).

\section{Discussion}

Peripheral neuroectodermal tumour, also referred to as peripheral neuroepithelioma, or malignant primitive neuroectodermal tumour, belongs to a group of tumours exhibiting features of neural differentiation $(4,5)$. Children and young adults are the commonly affected group $(4,5)$. They are reported to present as rapidly growing, painful soft tissue masses, which may show origin from a major nerve $(4,5)$. These tumours are included in the category of small round cell tumours, which encompass tumours such as neuroblastoma, Ewing's sarcoma, embryonal rhabdomyosarcoma, small cell osteogenic sarcoma and lymphoma (6). The current theory is that Ewing's sarcoma, Askin's tumour of the thoracic wall, and peripheral neuroectodermal tumour, belong to the family of neoplasms termed the "Ewing's sarcoma group", all of which show cytogenetic similarities $(7,8)$. They

Table 2. Histology and immunohistology of 7 patients with PNET

\begin{tabular}{|c|c|c|c|c|c|c|c|c|}
\hline $\begin{array}{l}\text { Case } \\
\text { No. }\end{array}$ & Histology & $\begin{array}{l}\text { Cytoplasmic } \\
\text { glycogen }\end{array}$ & $\begin{array}{l}\text { Reticuclin } \\
\text { pattern }\end{array}$ & NSE & NF & PGP 95 & $\begin{array}{c}\text { CK, EMA } \\
\text { CFA, LCA } \\
\text { Desmin } \\
\text { Actin } \\
\end{array}$ & Diagnosis \\
\hline 1. & $\begin{array}{l}\text { Small round cells } \\
\text { in sheets }\end{array}$ & + & Pericellular & + & & + & - & $\begin{array}{l}\text { PNET } \\
\text { Askin's } \\
\text { tumour }\end{array}$ \\
\hline 2. & $\begin{array}{l}\text { Small round cells } \\
\text { lobular growth } \\
\text { pattern }\end{array}$ & - & Sparse & + & & & - & $\begin{array}{l}\text { PNET } \\
\text { Soft } \\
\text { tissue }\end{array}$ \\
\hline 3. & $\begin{array}{l}\text { Larger cells } \\
\text { Rosettes ++ }\end{array}$ & - & Absent & + & & & - & $\begin{array}{l}\text { PNET } \\
\text { Soft } \\
\text { tissue }\end{array}$ \\
\hline 4. & $\begin{array}{l}\text { Small round cells in } \\
\text { sheets }\end{array}$ & - & $\begin{array}{l}\text { Pericellular } \\
\text { focally }\end{array}$ & + & & + & - & $\begin{array}{l}\text { PNET } \\
\text { of bone }\end{array}$ \\
\hline 5. & $\begin{array}{l}\text { Small round cells in } \\
\text { sheets }\end{array}$ & ++ & $\begin{array}{l}\text { Pericellular } \\
\text { focally }\end{array}$ & + & + & & - & $\begin{array}{l}\text { PNET } \\
\text { of bone }\end{array}$ \\
\hline 6. & $\begin{array}{l}\text { Medium sized cells } \\
\text { in sheets }\end{array}$ & - & Absent & + & & + & - & $\begin{array}{l}\text { PNET } \\
\text { Soft } \\
\text { tissue }\end{array}$ \\
\hline 7. & $\begin{array}{l}\text { Round cells with } \\
\text { rosettes and pseudo- } \\
\text { rosettes. Lobular } \\
\text { growth pattern. }\end{array}$ & - & $\begin{array}{l}\text { Pericellular } \\
\text { focally }\end{array}$ & + & + & + & - & $\begin{array}{l}\text { PNET } \\
\text { Soft } \\
\text { tissue }\end{array}$ \\
\hline
\end{tabular}



cases in Sri Lanka

are believed to form a spectrum, with Ewing's sarcoma at one end, and the peripheral neuroectodermal tumour showing neural differentiation at the other end(7). It is however, important to distinguish between Ewing's sarcoma and PNET, as the latter tends to behave more aggressively and is less chemosensitive.

Histologically PNET can show neural differentiation by the formation of resettes, or have a nondescript small-cell-tumour-like appearance. The mainstay of dagnosis is to demonstrate neural differentiation by immunohistochemical and ultrastructural techniques(5). The commonly used neural markers are neurone specific enolase, PGP 9.5, S-100 protein and neurofilamants, all of which can be demonstrated immunohistochemically. Electron microscopic demonstration of interdigitating cell processes, microtubules, and neurosecretory granules although providing conclusive evidence, is not carried out routinely.

The present study shows PNET to occur in children and adults, and as reported in other studies, shows dominance in the younger age group. The location of the tumour was varied and included soft tissue, bone and skin. Histologically only two cases showed rosette formation, and the others showed non-specific histological features (Table 2). Cytoplasmic glycogen was variable. The reticulin pattern was non-specific, failing to be of any diagnostic use. Immunohistochemistry showed cytoplasmic positivity for NSE in all cases. All except case 3, showed either neurofilaments or PGP 9.5 to be also positive (Table 2). O-13 was positive in case 2 . These results confirmed that the tumours were PNETs.

Case 1 was a young female and the tumour was located in the chest wall, with extensive involvement of the pleura and lungs. The tumour cells contained glycogen, and showed positive neural markers. All these features merited the diagnosis of Askin's tumour.

The tumour in case 2, was located in the eye lid. Since this was a child, secondaries from retinoblastoma and neuroblastoma were considered, and excluded clinically.

In case 4, a small cell osteosarcoma, and in case 5 an Ewing's tumour would enter into the differential diagnosis. However, since the neural markers were positive, these were categorised as PNETs. This distinction is relevant in the context of differences in responses to treatment. Case 4 died soon after diagnosis. Case 6 had multiple scalp lumps, involvement of both eyes and bone marrow. These were most likely secondary deposits from an undisclosed primary. The tumour regressed dramatically with chemotherapy. The final outcome however is not known. A primary such as neuroblastoma or retinoblastoma, were unlikely in this case - the patient being a young adult rather than a child. In case 7, the tumour showed good neural differentiation. This patient had a prolonged illness over a 3 year period, with several recurrences and extensive metastasis via lymphatics and the blood stream, to which he subsequently succumbed.

It is clear, from these observations that the PNETs tend to have an aggressive and relentless course.

\section{Conclusions}

PNETs occur at all ages amongst Sri Lankans but is commoner in the young. They present as primary or metastatic disease, in bone, soft tissue and skin. Histologically, most tumours show non specific appearances, and histological features alone are not useful in making an accurate diagnosis. All tumours showed conclusive evidence of neural differentiation on immunohistochemical staining for NSE, neurofilaments, PGP 9.5 and O-13. Histological features alone do not always enable a correct diagnosis to be made and specialised staining for neural markers must be done.

\section{Acknowledgments}

I wish to thank Dr. C. D. M. Fletcher, of the Soft Tissue Unit of St. Thomas's Hospital, London, for his help with the immunostains, 
Miss Sujatha Ramadasa for carrying out the immunostains, Mr. K. Herath for technical assistance, and Miss C. Sugathapala for typing the manuscript. I also thank Dr. S. C. A. Abeykoon, Consultant Radiotherapist and Oncologist, Cancer Institute Maharagama, for providing follow up details of case 6 .

\section{References}

1. Hashimoto H, Enjoji M, Nikajima T, Kiryu $\mathrm{H}$, Daimaru Y. Malignant neuroepithelioma - (Peripheral neuroblastoma): A clinicopathologic study of 15 cases. American Journal of Surgical Pathology 1983; 7: 309-318.

2. Triche TJ, Askin FB. Neuroblastoma and the differential diagnosis of small round blue cell tumours. Human Pathology 1983; 14: 569-595

3. Jurgens $H$, Bier V, Harms D, Beck J, Brandeis W, Etspuler G, Gadner H, Schmidt D, Treuner J, Winkler K, Gobel U. Malignant peripheral neuroectodermal tumours. A retrospective analysis of 42 patients. Cancer 1988; 61: 349-357.
4. Oxford textbook of pathology. Volume $2 b$ Editors: James OD McGee, Peter G. Isaacson, Nicholas A. Wright. Oxford University Press 1992; pp. 2126-2127.

5. Ackerman's Surgical Pathology. Volume 2 Editor: Juan Rosai. 7th edition. Washington DC C. V. Mosby Co. 1989; pp. 1614-1616.

6. Gariepy G, Drouin R, Lemieux N, Richer CL. Ultrastructural, immunohistochemical and cytogenetic study of a malignant peripheral neuroectodermal tumour in a patient seropositive for human immunodeficiency virus. American Journal of Clinical Pathology 1990; 93: 818-862.

7. Roessner A, Jurgens H. Round cell tumours of bone. Pathology: Research and Practice 1993; 189: 1111-1136.

8. Ladanyi $M$, Lewis $R$, Garin-Chesa P, Rettig WJ, Huvos AG, Healey J, Jhanwar SC. EWS rearrangement in Ewing's Sarcoma and peripheral neuroectodermal tumour. Molecular detection and correlation with cytogenetic analysis and MIC 2 expression. Diagnostic Molecular Pathology 1993; 2: 141-146. 